Grossiord, C., Christoffersen, B., Alonso-Rodríguez, A. M., Anderson-Teixeira, K., Asbjornsen, H., Aparecido, L. M. T., ... McDowe11, N. G. (2019). Precipitation mediates sap flux sensitivity to evaporative demand in the neotropics. Oecologia. https://doi.org/10.1007/s00442-019-04513-x

\title{
1 Precipitation mediates sap flux sensitivity to evaporative demand in the neotropics
}

3 Charlotte Grossiord ${ }^{1,2} *$, Bradley Christoffersen ${ }^{3}$, Aura M. Alonso-Rodríguez ${ }^{4}$, Kristina

4 Anderson-Teixeira $^{5,6}$, Heidi Asbjornsen ${ }^{7}$, Luiza Maria T. Aparecido ${ }^{8,9}$, Z. Carter Berry ${ }^{10}$,

5 Christopher Baraloto ${ }^{11}$, Damien Bonal ${ }^{12}$, Isaac Borrego ${ }^{2}$, Benoit Burban $^{13}$, Jeffrey Q.

6 Chambers $^{14,15}$, Danielle S. Christianson ${ }^{16}$, Matteo Detto ${ }^{17,18}$, Boris Faybishenko ${ }^{14}$, Clarissa G.

7 Fontes $^{19}$, Claire Fortunel ${ }^{20,21}$, Bruno O. Gimenez ${ }^{22}$, Kolby J. Jardine ${ }^{15}$, Lara Kueppers ${ }^{14}$,

8 Gretchen R. Miller ${ }^{23}$, Georgianne W. Moore ${ }^{9}$, Robinson Negron-Juarez ${ }^{14}$, Clément Stahl ${ }^{13}$,

9 Nathan G. Swenson ${ }^{24}$, Volodymyr Trotsiuk ${ }^{1,25,26}$, Charu Varadharajan ${ }^{14}$, Jeffrey M. Warren ${ }^{27}$,

10 Brett T. Wolfe ${ }^{18,28}$, Liang Wei ${ }^{2}$, Tana E. Wood ${ }^{4}$, Chonggang $\mathrm{Xu}^{2}$, Nate G. McDowell ${ }^{29}$

$12 *$ These two authors contributed equally to this work.

$13{ }^{1}$ Swiss Federal Institute for Forest, Snow and Landscape Research WSL, Zürcherstrasse 111,

148903 Birmensdorf, Switzerland

$15{ }^{2}$ Earth and Environmental Sciences Division, Los Alamos National Laboratory, Los Alamos,

16 NM, USA

$17{ }^{3}$ Department of Biology and School of Earth, Environmental, and Marine Sciences, University of

18 Texas Rio Grande Valley, Edinburg, TX, USA

$19{ }^{4}$ USDA Forest Service, International Institute of Tropical Forestry, Jardín Botánico Sur, 1201

20 Calle Ceiba, Río Piedras, PR 00926-1115, USA

$21{ }^{5}$ Center for Tropical Forest Science-Forest Global Earth Observatory, Smithsonian Tropical

22 Research Institute, Panama City, Panama 
$23{ }^{6}$ Conservation Ecology Center, Smithsonian Conservation Biology Institute, Front Royal, VA, 24 USA

$25{ }^{7}$ Department of Natural Resources and the Environment, University of New Hampshire, Durham, 26 NH 03824, USA

$27{ }^{8}$ School of Life Sciences, Arizona State University, AZ, USA

$28{ }^{9}$ Department of Ecosystem Science and Management, Texas A\&M University, College Station, 29 TX, USA

$30 \quad{ }^{10}$ Schmid College of Science and Technology, Chapman University, Orange, CA, USA

$31{ }^{11}$ International Center for Tropical Botany (ICTB), Department of Biological Sciences, Florida

32 International University, Miami, FL, USA

$33 \quad{ }^{12}$ Université de Lorraine, AgroParisTech, INRA, UMR Silva, 54000 Nancy, France

$34{ }^{13}$ INRA, UMR EcoFoG, CNRS, Cirad, AgroParisTech, Université des Antilles, Université de

35 Guyane, 97310 Kourou, France

$36{ }^{14}$ Department of Geography, University of California, Berkeley, Berkeley, CA, United States

$37{ }^{15}$ Climate and Ecosystem Sciences Division, Lawrence Berkeley National Laboratory, Berkeley, 38 CA, United States

$39{ }^{16}$ Computational Research Division, Lawrence Berkeley National Laboratory, Berkeley, CA, 40 USA

$41{ }^{17}$ Department of Ecology and Evolutionary Biology, Princeton University, Princeton, NJ, USA

$42 \quad{ }^{18}$ Center for Tropical Forest Science, Smithsonian Tropical Research Institute, Panamá,

43 República de Panamá

$44{ }^{19}$ Department of Integrative Biology, University of California Berkeley, Berkeley, CA 94720453140, USA 
${ }^{20}$ Department of Integrative Biology, University of Texas at Austin, Austin, TX, USA

$47{ }^{21}$ AMAP (botAnique et Modélisation de l'Architecture des Plantes et des végétations), IRD,

48 CIRAD, CNRS, INRA, Université de Montpellier, Montpellier, France

$49 \quad{ }^{22}$ Instituto Nacional de Pesquisas da Amazônia (INPA), Brazil

$50 \quad{ }^{23}$ Zachry Department of Civil Engineering, Texas A\&M University, 3136 TAMU, College

51 Station, TX, USA

$52{ }^{24}$ Department of Biology, University of Maryland, College Park, MD, USA

$53{ }^{25}$ ETH Zurich, Department of Environmental Systems Science, Institute of Agricultural Sciences,

548092 Zurich, Switzerland

$55 \quad{ }^{26}$ Czech University of Life Sciences Prague, Faculty of Forestry and Wood Sciences, Kamýcká

56 129, Praha 6, Suchdol 16521, Czech Republic

$57{ }^{27}$ Climate Change Science Inst. and Environmental Sciences Division, Oak Ridge National

58 Laboratory, Oak Ridge, TN, USA

$59{ }^{28}$ School of Renewable Natural Resources, Louisiana State University, Baton Rouge, LA, USA

$60 \quad{ }^{29}$ Earth Systems Science Division, Pacific Northwest National Laboratory, Richland, WA, USA

61

62 Corresponding author: Charlotte Grossiord, charlotte.grossiord@wsl.ch, +41447392069

64 Author Contributions: CG, BC, JW and NGM planned the research. AA, HA, BB, BG, BW,

$65 \mathrm{CB}, \mathrm{CB}, \mathrm{CS}, \mathrm{CF}, \mathrm{DB}, \mathrm{DC}, \mathrm{MD}, \mathrm{BF}, \mathrm{CF}, \mathrm{KJ}, \mathrm{GRM}, \mathrm{GWM}, \mathrm{CV}, \mathrm{JW}, \mathrm{BW}, \mathrm{NS}, \mathrm{LA}, \mathrm{TEW}$ and

66 LW contributed data. CG and BC analyzed the data and wrote a first draft of the manuscript, and

67 all authors contributed to revisions. 
Abstract

69 Transpiration in humid tropical forests modulates the global water cycle and is a key driver of

70 climate regulation. Yet, our understanding of how tropical trees regulate sap flux in response to

71 climate variability remain elusive. With a progressively warming climate, atmospheric

72 evaporative demand (i.e., vapor pressure deficit, $V P D$ ) will be increasingly important for plant

73 functioning, becoming the major control of plant water use in the $21^{\text {st }}$ century. Using

74 measurements in 34 tree species at seven sites across a precipitation gradient in the neotropics,

75 we determined how the maximum sap flux velocity $\left(v_{\max }\right)$ and the VPD threshold at which $v_{\max }$ is

76 reached $\left(V P D_{\max }\right)$ vary with precipitation regime (mean annual precipitation, $M A P$; seasonal

77 drought intensity, $\left.P_{D R Y}\right)$ and two functional traits related to foliar and wood economics spectra

78 (leaf mass per area, $L M A$; wood specific gravity, WSG). We show that, even though $v_{\max }$ is

79 highly variable within sites, it follows a negative trend in response to increasing $M A P$ and $P_{D R Y}$

80 across sites. $L M A$ and $W S G$ exerted little effect on $v_{\max }$ and $V P D_{\max }$, suggesting that these

81 widely-used functional traits provide limited explanatory power of dynamic plant responses to

82 environmental variation within hyper-diverse forests. This study demonstrates that long-term

83 precipitation plays an important role in the sap flux response of humid tropical forests to VPD.

84 Our findings suggest that under higher evaporative demand, trees growing in wetter

85 environments in humid tropical regions may be subjected to reduced water exchange with the

86 atmosphere relative to trees growing in drier climates.

88 Keywords: evapotranspiration, plant functional traits, transpiration, vapor pressure deficit. 
Humid tropical forests cover approximately $12 \%$ of global ice-free land surface area

91 (Mayaux et al. 2005) and are characterized by high mean annual precipitation (> $1500 \mathrm{~mm}$ ) with

92 low variability in atmospheric temperature $\left(\approx 25 \pm 5^{\circ} \mathrm{C}\right)$ (Richards 1952 ; Murphy and Lugo,

93 1986). The majority of water entering tropical forests through precipitation or rivers is returned

94 to the atmosphere via evapotranspiration (Moreira et al. 1997; Kumagai et al. 2016). Water

95 released by trees in their transpiration flux largely contributes to total evapotranspiration in the

96 tropics (Schlesinger and Jasechko 2014), 35\% of which is cycled back to the biome as

97 precipitation (Eltahir and Bras 1994; Zemp et al. 2014). As such, tree transpiration in tropical

98 forests is a major modulator of the global water cycle and plays a central role in climate

99 regulation (Foley et al, 2007). Yet, despite our efforts in understanding transpiration patterns of

100 tropical trees (e.g., Meinzer et al. 2003; Stahl et al. 2013a; Maréchaux et al. 2018), how trees

101 regulate water use in these ecosystems remains one of the largest uncertainty components in

102 models of tropical evapotranspiration.

At daily to seasonal time-scales, trees regulate their transpiration flux in response to

104 variation in atmospheric evaporative demand (i.e., vapor pressure deficit, VPD), radiation, wind

105 and available soil water (Oren et al. 1999; Meinzer et al. 2001). Under non-limiting soil water

106 availability, radiation and VPD are usually the most significant climate variables controlling

107 water flux in tropical trees (e.g., Meinzer et al. 2008). However, global warming will result in an

108 exponential climb in VPD in the next decades (Zhang et al. 2015), and the relative role of these

109 two abiotic drivers (i.e., radiation $v s . V P D$ ) is expected to shift in the future with $V P D$ becoming

110 the major control of plant water use in the $21^{\text {st }}$ century (Novick et al. 2016). Therefore,

111 improving our understanding of water use patterns and their response to VPD, including the 
112 linkages to predictive plant traits, is an important next step with major implications for global 113 climate and vegetation predictions.

114 While over long periods (i.e. years to decades), stand water use is mainly regulated by 115 changes in leaf area and species composition, over short-term periods (i.e. hours to days), trees 116 regulate sap flux velocity (v) (Edwards et al. 1996) through changes in stomatal conductance.

117 Thus, $v$ response to daily $V P D$ variation directly depends on the degree of stomatal closure 118 (Schulze et al. 1972). Under low VPD conditions, plant stomata are fully open and $v$ increases 119 linearly with $V P D$ (Franks et al. 1997), until $v$ reaches a saturation rate $\left(v_{\max }\right.$, Fig. 1$)$ at a given $120 V P D$ threshold $\left(V P D_{\max }\right.$, Fig. 1). As $V P D$ increases, trees progressively start closing their 121 stomata, and for some species, including tropical trees, stomatal closure can be so pronounced as 122 to result in a decreased rate of $v$ (Fig. 1) (Schulze et al. 1972; Franks et al. 1997). The degree of 123 sap flux response to $V P D$ varies both within and between species because of differences in local 124 climatic adjustments and ecological strategy. For instance, trees originating from distinct 125 precipitation regimes should differ in their sap flux responses to VPD because of adaptive 126 mechanisms in response to moisture conditions, including wood hydraulic properties and foliar 127 traits (Mencuccini 2003; Poyatos et al. 2007). Trees growing in drier climates may produce 128 xylem elements with reduced lumen areas relative to trees from wetter climates to reduce the risk 129 of xylem embolism and promote overall hydraulic safety (Hacke et al. 2004; Fonti and Jansen 130 2012). Anatomical changes in these conductive tissues will directly alter the sap flux patterns of 131 trees (i.e. reduced $v$ in drier systems), and have been associated to reduced $V P D_{\max }$ and $v_{\max }$ in 132 dry ecosystems (Grossiord et al. 2017; 2018). Similarly, reductions in soil moisture during dry 133 periods have been linked with changes in stomatal density (Luomala et al. 2005) and in the 134 synthesis of chemical signals inducing stomatal closure (Schachtman and Goodger 2008), which 
135 should also reduce $V P D_{\max }$ and $v_{\max }$ in forests that are subjected to seasonal droughts. In humid 136 tropical forests, regional variability in annual precipitation (from 1500 to $>4000 \mathrm{~mm}$ annually)

137 and in dry season intensity is high, suggesting large variation in plant physiological and

138 structural adjustments to moisture status, and thus potentially important differences in $V P D_{\max }$

139 and $v_{\max }$ between ecosystems. However, soil moisture is usually less limiting in humid tropical

140 forests than in temperate and semiarid regions where reductions in $V P D_{\max }$ and $v_{\max }$ following

141 precipitation reduction have been reported (Grossiord et al. 2018). As such, this characteristic

142 physiological or hydraulic adjustment to soil moisture limitation may not occur in this biome,

143 suggesting that acclimation processes to water stress would only occur under a given

144 precipitation and/or drought intensity threshold.

145 A difficulty in making predictions on the functioning of humid tropical forests lies in the 146 fact that these ecosystems host more tree species than any other terrestrial ecosystem (Myers et 147 al. 2000). Large species diversity in the tropics is accompanied by large diversity in plant 148 functional traits (Wright et al. 2007; Baraloto et al. 2010; Fortunel et al. 2012; 2014; Zhu et al. 149 2013; Cosme et al. 2017). Functional differences that directly alter $v$ regulation include rooting 150 properties (e.g. water uptake depth, Stahl et al. 2013b; Brum et al. 2019), hydraulic properties

151 (e.g. lumen area or water potential at 50\% loss of hydraulic conductivity $\mathrm{P}_{50}$; Litvak et al. 2012) 152 and foliar characteristics (e.g. stomatal density or leaf turgor loss point; Bartlett et al. 2012, 153 Maréchaux et al. 2018). However, while such mechanistic trait data are growing in availability 154 for tropical forests, they remain poorly quantified relative to more easily measurable traits such 155 as leaf mass per area (LMA) and wood specific gravity (WSG) (Wright et al. 2004; Chave et al. 156 2014). LMA and WSG respectively comprise the well-studied leaf and wood economics spectra, 157 which have been successfully related to various aspects of plant function along a fast (resource- 
158 acquisitive, low LMA and WSG)-to-slow (resource-conservative, high LMA and WSG) continuum

159 (Reich et al. 1997; but see Baraloto et al. 2010; Fortunel et al. 2012). These traits only indirectly

160 relate to dynamic physiological processes such as $F_{D}$ (Brodribb 2017), however $L M A$ and WSG

161 can be used to support mechanistic theory of moisture adjustments in modelling frameworks by

162 correlating with other plant traits related to hydraulic transport (Christoffersen et al. 2016). As

163 such, we might expect trees originating from drier regions in humid tropical forests, and thus

164 with lower $V P D_{\max }$ and $v_{\max }$, to have higher $L M A$ and $W S G$ (i.e. two typical adjustment responses

165 to reduced moisture, Wright et al. 2005) relative to trees with higher $V P D_{\max }$ and $v_{\max }$.

166 Here we analyzed how trees regulate sap flux velocity in response to VPD variation in 34

167 species originating from seven sites along a precipitation gradient in the neotropics. Our

168 objectives were to test how long-term local precipitation regime (annual precipitation and

169 intensity of the dry season) modulate $V P D_{\max }$ and $v_{\max }$, and detect whether variation in $V P D_{\max }$

170 and $v_{\max }$ across sites can be related to the variability in two easy-to-measure functional traits:

$171 \quad L M A$ and $W S G$. We hypothesized that:

172 1) trees growing in relatively dry regions and that are subjected to more frequent and intense 173 droughts would show reduced $V P D_{\max }$ and $v_{\max }$ compared to trees originating from wetter

174 areas because of long-term physiological and structural adjustments to reduced soil

175 moisture availability (Mencuccini 2003) (Fig. 1),

1762 2) across all sites, trees with higher $L M A$ and $W S G$ would show reduced $V P D_{\max }$ and $v_{\max }$

177 relative to trees with low LMA and WSG. 
179 Study sites

We used data collected from mature humid tropical forests in seven sites spanning from

181 Puerto Rico to northern Brazil (Table 1, Figs. S1 \& S2). The focal sites are located in Puerto

182 Rico (SAB hereafter), Costa Rica (SOL), Panama (SLZ, BCI and PNM), French Guiana (FRG)

183 and Brazil (MAN). The target tree species pool (representing among the most abundant tree

184 species within each site) varied between four and nine per site (Table 2), leading to a total of 34

185 tree species included in this study with only one species being present at multiple sites (Table

186 S1). Climatic conditions (rainfall, air temperature, atmospheric humidity and solar radiation)

187 were measured continuously and recorded by local weather stations at all sites during the 188 measurements.

All sites, apart from the SOL site, experience a dry season (i.e., monthly precipitation <

$190100 \mathrm{~mm}$ ) of approx. three months. Long-term precipitation was used to characterize long-term 191 annual moisture status and drought intensity in each site using the site-level average in annual

192 sum of precipitation $(M A P)$ and monthly precipitation during the dry season $\left(P_{D R Y}\right)$ over the

193 1950-2010 period. When long-term site-specific data was not available (all sites except PNM,

194 BCI and SLZ), long-term precipitation was extracted for each site using Twentieth Century

195 Reanalysis Project, a 2.0-degree latitude and 2.0-degree longitude global climate dataset (Compo 196 et al. 2011). The sites were characterized by contrasting precipitation regimes varying between

1971826 and $4200 \mathrm{~mm}$ on average annually over the 1950-2010 period, with the PNM site (Panama)

198 being the driest and the SOL site (Costa Rica) the wettest (PNM $<$ MAN $<$ BCI $<$ SLZ $<$ FRG $<$

199 SAB < SOL) (Table 1). See Table 1 for more details on site characteristics and site-specific

200 references. 
203 In each site between four and nine trees that occupied dominant positions in the canopy (to

204 avoid effects related to crown exposure) were selected for this study, leading to a total of 43 trees

205 (Table 2). At all sites, tree sap flux velocity $\left(v ; \mathrm{cm} \mathrm{h}^{-1}\right)$ was measured every $10 \mathrm{~min}, 15 \mathrm{~min}, 30$

206 min or hour using either the thermal dissipation method (Granier 1987) or the heat ratio method

207 (Burgess et al. 1998). Depending on the site, sensors were bought from manufacturers (SFM1,

208 ICT International, NSW, Australia; UP-Gmbh, Cottbus, Germany; PS-GP, PlantSensors, Nakara,

209 Australia) or lab-built. Measurements were conducted continuously for periods varying between

210 two and 24 months (Table 1) between January 2014 and January 2017. For the thermal

211 dissipation method, sensors (i.e. one sensor per tree except for the SOL site where two sensors

212 per tree were installed, 10- or 20-mm long) were installed in the sapwood at $1.3 \mathrm{~m}$ aboveground

213 or above buttresses with a $10 \mathrm{~cm}$ vertical spacing between probes. For the heat-ratio method (i.e.

214 one sensor per tree), each set of sensors consisted of two or three thermocouples and one-line

215 heater probe. The thermocouples were inserted at $1.3 \mathrm{~m}$ aboveground at depths varying between

2162.2 and $3 \mathrm{~cm}$ below the cambium. The sensors were covered with reflective insulation to reduce

217 the risk of direct sunlight causing thermal gradients. The data were recorded continuously by

218 dataloggers (CR800, CR10X and CR1000, Campbell Scientific Corp., Logan, UT, USA), apart

219 from the SFM1 sensors that contain a stand-alone datalogger. For more details see the site-

220 specific references in Table 1. 
224 framework, consisting of three associated metadata files, respectively describing the data files, 225 the columns of each data file, and field observations of tree size, canopy position, and species 226 identity, if available (Christianson et al. 2017). We collated the raw data for all sites via a series 227 of R scripts, which interpreted each dataset in terms of its associated metadata file (code 228 available in the supplement of Christianson et al. 2017).

229 We started data processing using the raw $\mathrm{mV}$ values outputted by the sap flux sensors.

230 Sap flux velocity data from the SOL site had already been converted to $v\left(\mathrm{~cm} \mathrm{~h}^{-1}\right)$ using the

231 Granier equation (1987) (see Aparecido et al. 2016 for more details). The open-source Baseliner

232 software (Oishi et al. 2016) was used to calculate $v$ values for each tree following the equation

233 proposed by Granier (1987). No species-specific equations are available for the tropical species

234 included in this study, and thus care must be taken when interpreting $v$ results as the empirically

235 derived coefficients in the Granier equation may introduce errors in $v$ calculations (Bush et al.

236 2010). Baseliner enables users to control the quality and process data using a combination of

237 automated steps and manual editing (Oishi et al. 2016). Missing data were gap filled when they

238 were shorter than two hours using linear interpolation (Oishi et al. 2016). Estimation of baseline

239 nighttime flow is done automatically in Baseliner based on a joint set of conditions, including

240 nighttime hours (characterized by near-zero radiation), stable temperature differential between

241 probes (estimated using coefficient of variation) and low VPD (see Oishi et al. 2016 for more

242 details).

243 After converting all values into $v$, we conducted a systematic removal of values

244 associated with measurement failures and sensor removals in the field. For the MAN, PNM, SLZ

245 and BCI sites, we removed all days before DOY 175 in 2016 (corresponding to the 2015-2016 
246 ENSO event) to avoid potential $v$ responses to anomalously low soil moisture (Fig. S3). In

247 addition, sub-hourly $v$ data was visually assessed for all trees to ensure no drought period was

248 included in the final dataset. The FRG site included semi-deciduous tree species, which

249 experienced leaf drop during the measurement periods. To avoid effects related to changes in

250 leaf area induced by significant leaf drop, these periods were removed from the analyses.

251 Individual-tree $v$ time series are presented for each site in Fig. S4. The two methods used for

252 measuring $v$ (heat ratio method $v s$. thermal dissipation method) have been shown to vary in their

253 accuracy to measure absolute $v$ rates (Steppe et al. 2010). However, tests conducted at the MAN

254 and SLZ sites (i.e. the two sites where the heat ratio method was used), where both sensor types

255 were collocated on individual trees, indicated no significant differences in $v$ rates between the

256 two methods (Fig. S5). No information on the depth of the active sapwood was available for the

257 target trees, but to our knowledge, no study reported radial changes in $v$ patterns to VPD

258 variation.

Estimation of maximum sap flux velocity and VPD at which sap flux velocity reaches maximum

261 values

To avoid confounding effects of radiation we applied a radiation filter for each site by

263 removing all $v$ data where sub-hourly radiation was below the $90^{\text {th }}$ percentile of daytime

264 radiation values. For most sites this threshold was equal to $600 \mathrm{~W} \mathrm{~m}^{-2}$ apart for the BCI and FRG

265 sites where the threshold was equal to $700 \mathrm{~W} \mathrm{~m}^{-2}$ (Fig S6). Using sub-hourly $v$ data, we estimated

266 the maximum sap flux velocity $\left(v_{\max }\right.$, Fig. 1$)$ for each tree as the $95^{\text {th }}$ percentile of $v$ values after

267 applying the radiation filter (Fig. S7). The $V P D$ value at which $v$ reaches maximum levels

$268\left(V P D_{\max }\right.$, Fig. 1) was estimated as the $2.5^{\text {th }}$ percentile of $V P D$ values corresponding to $v_{\max }$ (Fig. 
269 S7). All the analysis was done using the R language for statistical computing (3.2.1, $R$

270 Development Core Team 2015).

271

$272 \quad$ Functional traits

273 To analyze how variation in $V P D_{\max }$ and $v_{\max }$ could be related to foliar and wood

274 functional traits, we used leaf mass per area $\left(L M A, \mathrm{~g} \mathrm{~m}^{-2}\right)$ and wood specific gravity $\left(W S G, \mathrm{~g} \mathrm{~cm}^{-}\right.$

$275^{3}$ ). Investigation of other traits (e.g., wood anatomy, leaf-to-sapwood area ratio) revealed a

276 paucity of data for the target tree species, thus we focused strictly on LMA and WSG. When

277 possible, we used direct measurements on the sampled trees during the sap flux measurements.

278 Conversely, when the trait measurements were not available for our focal trees, we used

279 previously published data originating from the same species (see sources in Table S1). In total,

280 data on LMA and WSG were gathered for $31(73 \%)$ and $39(91 \%)$ trees (for LMA and WSG,

281 respectively) (Table $\mathrm{S} 1)$.

282

283 Statistical analyses

284 The impacts of long-term $M A P\left(\right.$ or $P_{D R Y}$ ), $L M A$ and $W S G$ on $V P D_{\max }$ and $v_{\max }$ were

285 determined first by fitting linear models, followed by closer examination using linear mixed

286 effect models (package $l m e$ ) where $M A P$ (or $\left.P_{D R Y}\right), L M A, W S G$, diameter at breast height $(D B H$,

287 i.e. to account for effects related to tree size) and their interactions were used as fixed effects,

288 and trees nested in sites was used as a random effect. The model selection procedure started with

289 all variables and by progressively removing the variables with the lowest explanatory power

290 until the minimal model with the lowest Akaike Information Criterion (AIC) was obtained. 
291 Models were compared using 'anova' test to select the least complex parsimonious model. In all

292 cases, the linear model (package $l m$ ) with $M A P$ or $P_{D R Y}$ was selected. The same tests were used

293 to detect the impact of $M A P$ (or $P_{D R Y}$ ) on $L M A$ and $W S G$, with $M A P$ (or $P_{D R Y}$ ), DBH and their

294 interaction used as fixed effects. 


\section{Results}

296

297

298

299

300

301

302

303

304

305

306

307

308

309

310

311

312 $31{ }^{1}$, depending on the individual tree (Fig. 2).

314 Precipitation
to $2.94 \mathrm{kP}$
(Fig. S8). Th) in all sitween 0 a
betwong varia
response to
ant diversity
with $V P D$ u
a few trees,

Climatic conditions

(1950-2010) in all sites (Fig. S3). Mean daily air temperature and $V P D$ ranged from 18 to $28^{\circ} \mathrm{C}$, and 0.47 to $2.94 \mathrm{kPa}$, respectively, during the measurement period, depending on the sites and seasons (Fig. S8). The sites experienced a range of VPD values during sap flux measurements varying between 0 and approx. $4.3 \mathrm{kPa}$ (Fig. 2).

\section{Sap flux response to VPD variation}

important diversity of water use strategies between species (Fig. S4). For most trees, $v$ increased linearly with $V P D$ until reaching a saturation rate $\left(v_{\max }\right)$ at a given $V P D$ threshold $\left(V P D_{\max }\right.$, Fig.

2). For a few trees, $v$ decreased with rising $V P D$ after reaching a saturation rate, suggesting strong stomatal closure, while other trees showed no distinctive saturation rate with rising $V P D$ (Fig. 2). Trees displaying a decline in $v$ at high $V P D$ did not have significantly different $L M A$ or $W S G$ from trees without such a decline (Welch's two-sided t-test: $\mathrm{t}=0.257, \mathrm{df}=4.05, P=0.810$; $\mathrm{t}=0.169, \mathrm{df}=4.75, P=0.873$, respectively). In general, $v_{\max }$ was reached when $V P D_{\max }$ varied between 0.6 and $2.0 \mathrm{kPa}$, depending on the trees (Fig. 2). $v_{\max }$ varied between 4.1 and $41.4 \mathrm{~cm} \mathrm{~h}^{-}$

315 at wetter sites and higher values at drier sites. The driest site, PNM, had the highest values (mean 316 of $1.5 \mathrm{kPa}$ and $24.7 \mathrm{~cm} \mathrm{~h}^{-1}$ for $V P D_{\max }$ and $v_{\max }$, respectively), while the wettest site, SOL, had 
317 the lowest $v_{\max }\left(\right.$ mean of $\left.7.7 \mathrm{~cm} \mathrm{~h}^{-1}\right)$. There were significant negative effects of MAP on $v_{\max }\left(\mathrm{r}^{2}=\right.$ 3180.32 , slope $=-0.006, P<0.001)$ but not on $V P D_{\max }\left(\mathrm{r}^{2}=0.10\right.$, slope $\left.=-0.000, P=0.062\right)($ Fig. 3). 319 A significant negative effect of $P_{D R Y}$ was found for $v_{\max }\left(\mathrm{r}^{2}=0.21\right.$, slope $\left.=-0.21, P=0.005\right)$, but 320 not for $V P D_{\max }\left(\mathrm{r}^{2}=0.00\right.$, slope $\left.=-0.000, P=0.842\right)($ Fig. 3). No relationship was found between $321 V P D_{\max }$ and $v_{\max }$ (Fig. S9), indicating no trade-off between the VPD threshold at which $v$ levels322 off at maximum rates and maximum $v$.

324 Relationships with functional traits

325 No effect of $L M A$ on $v_{\max }\left(\mathrm{r}^{2}=0.00, P=0.835\right)$, and $V P D_{\max }\left(\mathrm{r}^{2}=0.00, P=0.704\right)$ was 326 found. Similarly, no relationship between $W S G$ and $v_{\max }\left(\mathrm{r}^{2}=0.08, P=0.167\right)$, and $V P D_{\max }\left(\mathrm{r}^{2}=\right.$ $3270.02, P=0.542)$ were found (Fig. 4). There was no effect of $M A P$ or $P_{D R Y}$ on $L M A(P=0.722$ 328 and $P=0.600$, respectively), nor on $W S G(P=0.434$ and $P=0.290)$. A significant relationship 329 was observed between LMA and WSG (Fig. S9), suggesting a slight coupling between leaf and 330 stem economics in these trees (i.e. trees with higher $L M A$ tend to grow denser wood). 


\section{Discussion}

\section{Precipitation mediates sap flux response to evaporative demand in the neotropics}

Our findings highlight that sap flux response to $V P D$ under non-depleted soil moisture

334 conditions in humid tropical forests partially depends on average $M A P$ and $P_{D R Y}$ over the last 50

335 years, i.e., indicators of long-term moisture availability and drought stress intensity. More

336 specifically, our data show that as average site-level precipitation increases and seasonal drought

337 intensity decreases, trees attain lower maximum sap flux $\left(v_{\max }\right)$ when soil moisture is non-

338 limiting (Fig. 3). This relationship was not an artefact of reduced radiation at wetter sites because

339 of the radiation filter applied (Fig. S6). These findings contrast with previous observations from

340 Mediterranean and semiarid woodlands where increasing aridity resulted in reduced $v_{\max }$ (e.g.,

341 Poyatos et al. 2007; Grossiord et al. 2018), suggesting contrasting underlying adjustments to

342 moisture between supply-limited and demand-limited environments.

The negative response pattern of $v_{\max }$ to increasing $M A P$ and $P_{D R Y}$ observed here implies

344 that compared to dry temperate forests, tree sap flux velocity in humid tropical forests does not

345 depend on drought-adjustments to local climate (i.e. adjustments reducing the vulnerability to

346 water shortage) (Grossiord et al. 2018). Instead, sap flux patterns in response to climate

347 variability are probably dependent on adjustments to high-moisture conditions. Indeed, in the

348 sites included here, $V P D$ is usually low and precipitation is high compared to temperate and

349 semiarid regions, thus tree water relations are more rarely limited by high evaporative demand or

350 drought stress. One may therefore expect trees in this environment to have evolved functional

351 traits to deal with other limiting factors such as low radiation induced by the high cloud cover

352 (Moore et al. 2018). Furthermore, high atmospheric humidity can lead to sustained leaf wetness

353 with water films on leaves inhibiting gas exchanges, and resulting in reduced sensitivity to 
354 atmospheric drivers (Dawson and Goldsmith 2018; Moore et al. 2018). Plants that grow in high

355 atmospheric humidity conditions have also been reported to show low levels of endogenous

356 abscisic acid (ABA) (Nejad and Van Meeteren 2007; Okamoto et al. 2009), and marginal

357 stomata regulation on carbon and water fluxes (Torre and Fjeld 2001; Torre et al. 2003).

358 Therefore, an important research topic for future work, in addition to exploring adjustment

359 mechanisms to reduced precipitation, is to understand how adaptive mechanisms related to high

360 moisture could relate to sap flux regulation in tropical trees.

Lower $v_{\max }$ under non-limiting soil moisture conditions could potentially result in reduced

362 water exchange with the atmosphere in humid tropical forests as more days with high $V P D$ are

363 likely to occur in the future. Currently, Earth system models (ESM) are being developed to

364 incorporate plant hydraulic traits (Xu et al. 2016, Christoffersen et al. 2016, Kennedy et al.

365 2019), but it is not immediately clear if such traits will produce the patterns observed here for

366 humid tropical ecosystems. Incorporating traits related to adjustments to high-moisture

367 environments could potentially affect the differential responses of global precipitation to

368 vegetation changes (e.g., Kooperman et al. 2018). To gain further insight into the drivers of sap

369 flux variability, we suggest extending this work to more extreme sites, i.e. both wet and dry, and

370 exploring other relevant factors such as long-term indices of evaporative demand (Poyatos et al.

371 2007). Improved quantification of within-site variation, including systematic replication of

372 species sampled along environmental gradients would also be needed. Such an improved design

373 would be valuable for trait-enabled dynamic vegetation models (Fisher et al. 2018), even if

374 systematically sampling the same species in tropical forests may prove complicated considering

375 their high species diversity. 
378 the neotropics

We found a large variability in $L M A$ and $W S G$ within and across sites, reflecting the high

380 functional diversity present in these ecosystems (Fortunel et al. 2012). Nevertheless, the large

381 diversity in these functional traits could not be related to the variability in $V P D_{\max }$ and $v_{\max }$

382 observed across sites (Fig. 4). This is not so surprising in light of a recent review (Moles 2018)

383 that highlights a remarkable degree of inconsistency in reported relationships of LMA and WSG

384 with other plant traits related to plant ecological strategy or the fast-slow economic spectrum

385 (Reich 2014). Moreover, we expect that stem and leaf traits more directly related to acquisition,

386 transport, and retention of water (hydraulic traits) would underpin the patterns observed here;

387 appropriate trait selection is therefore critical for uncovering trait-moisture relationships more

388 generally (Griffin-Nolan et al. 2018). Specifically, reduction in moisture across large

389 environmental gradients has been associated with shifts in mechanistic foliar traits such as

390 stomatal density (e.g. Luomala et al. 2005) or chemical compounds inducing stomatal closure

391 (Schachtman and Goodger 2008). Investigating such anatomical and chemical foliar adjustments

392 that provide stronger mechanistic basis than LMA will be needed to unravel the underlying

393 adaptive processes driving $V P D_{\max }$ and $v_{\max }$ patterns along our precipitation gradient (Fig. 3).

394 Similarly, WSG had no detectable impact on $V P D_{\max }$ and $v_{\max }$ (Fig. 4). Wood density is

395 considered an important modulator of xylem water transport as higher wood density has been

396 associated with reduced hydraulic conductivity and higher resistance to xylem cavitation (Hacke

397 et al. 2004). As such, this property could constrain the maximum flux of water movement in

398 trees (Barbour and Whitehead 2003). However, most WSG measurements, including the ones

399 used in this study, are made using main stems. Yet, to be relevant for water transport, this trait 
400 should represent all woody tissues, from the roots to the canopy (Fortunel et al. 2012).

401 Furthermore, the interpretation of $W S G$ as an indicator of plant hydraulic functions is debated

402 (Larjavaara and Muller-Landau 2010), since a given WSG can be achieved under various

403 combinations of wood anatomy which do not necessarily impact water transport, but instead

404 reflect variability in the competing demands of strength and storage (Fortunel et al. 2014;

405 Zieminska et al. 2015; Morris et al. 2016; Dias et al. 2019).

Therefore, although $L M A$ and $W S G$ are useful for indicating, respectively, placement on

407 the leaf economics spectrum (Wright et al. 2004) and successional status in productivity models

408 (Moorcroft et al. 2001), they do so only at global scales and do not consistently relate to other

409 plant traits at local and regional scales (Moles 2018), as our findings also confirm here. They

410 appear to provide limited interpretation of dynamic plant responses to environmental variation

411 within hyper-diverse tropical forests (Brodribb 2017). While incorporation of such local

412 adjustments in ESMs is possible via trait-mediated plant responses to the environment (e.g.,

413 Fisher et al. 2015), the functional traits explored here, LMA and WSG, show little promise.

414 Focused data collection on more mechanistic traits associated with plant hydraulics and stomatal

415 function like for instance $\mathrm{P}_{50}$, leaf turgor loss point, cuticular conductance, sapwood anatomy,

416 stomatal density or foliar chemical compounds are likely to reveal mechanistic controls on the

417 interspecific differences in sap flow observed here, which can be used to refine existing plant

418 hydraulic models (Christoffersen et al. 2016; Wolf et al. 2016; Xu et al. 2016; Sperry et al. 419 2017).

421 Conclusion 
This study demonstrates that local climate plays an important role in the sap flux

423 response of humid tropical forests to evaporative demand. Moreover, we highlight that trees

424 growing in wetter regions in the tropics may be subjected to a reduced sap flux velocity with the

425 high evaporative demand predicted by most climate models. We expect incorporating these

426 regulation strategies in models could improve our prediction accuracy of both vegetation

427 dynamics and water cycles. This study also shows that easy-to-measure functional traits provide

428 little interpretation in dynamic sap flux response to $V P D$, suggesting that more mechanistic traits

429 should be investigated to build predictors in future models. Finally, it is important to note that

430 although our sampling included a large number of species relative to previous studies

431 investigating sap flux-climate responses, our work still covers only a limited range of the

432 incredible diversity present in humid tropical forests. Extending sap flux measurements in more

433 regions in the tropics and developing large databases of plant water use (e.g. SAPFLUXNET,

434 Poyatos et al. 2016) is an important next step if we want to improve our predictive capacity of

435 tropical forest responses to climate change. 


\section{Acknowledgments}

437 This project was supported in part by the Next Generation Ecosystem Experiments Tropics, 438 funded by the US Department of Energy, Office of Science, Office of Biological and

439 Environmental Research, Terrestrial Ecosystem Sciences Program, under Award Number DE-

440 SC-0011806. CG was supported by the Swiss National Science Foundation SNF

441 (5231.00639.001.01). BC was supported in part by the Laboratory Directed Research and

442 Development Program Project 8872 of Oak Ridge National Laboratory, managed by UT-

443 Battelle, LLC, for the U. S. Department of Energy. This work has benefited from an

444 “Investissements d'Avenir” grant managed by Agence Nationale de la Recherche (CEBA, ref. 445 ANR-10-LABX-25-01). Data recorded in French Guiana (FRG) were collected at the Guyaflux

446 sites which belong to the SOERE F-ORE-T and is supported annually by Ecofor, Allenvi and the

447 French national research infrastructure, ANAEE-F. We thank Valentine Herrmann for building 448 the probes for the Panamanian and Brazilian sites. We thank all technicians, students and post449 docs who helped collect data at all sites. 
451 Aparecido LMT, Miller GR, Cahill AT, Moore GW (2016) Comparison of tree transpiration 452 under wet and dry canopy conditions in a Costa Rican premontane tropical forest. Hydrological 453 Processes 30, 26: 5000-5011.

454 Baraloto C, Timothy Paine CE, Poorter L, Beauchene J, Bonal D, Domenach A-M, Hérault B, 455 Patiño S, Roggy J-C, Chave J (2010) Decoupled leaf and stem economics in rain forest trees. 456 Ecology Letters 13: 1338-1347.

457 Barbour MM, Whitehead D (2003) A demonstration of the theoretical prediction that sap 458 velocity is related to wood density in the conifer Dacrydium cupressinum. New Phytologist 158: $459 \quad 477-488$.

460 Bartlett MK, Scoffoni C, Sack L (2012) The determinants of leaf turgor loss point and prediction 461 of drought tolerance of species and biomes: a global meta-analysis. Ecology Letters 15: 393-405.

462 Bonal D, Bosc A, Ponton S, Goret J-Y, Burban B, Gross P, Bonnefond J-M, Elbers J, Longdoz

463 B, Epron D, Guehl J-M, Granier A (2008) Impact of severe dry season on net ecosystem

464 exchange in the Neotropical rainforest of French Guiana. Global Change Biology 14: 1917-1933.

465 Brodribb TJ (2017) Progressing from 'functional' to mechanistic traits. New Phytologist 215: 946611.

467 Brum M, Vadeboncoeur MA, Ivanov V, Asbjornsen H, Saleska S, Alves LF, Penha D, Dias JD, 468 Aragão LE, Barros F, Bittencourt P (2019) Hydrological niche segregation defines forest 469 structure and drought tolerance strategies in a seasonal Amazon forest. Journal of Ecology, 470 https://doi.org/10.1111/1365-2745.13022 
471 Burgess SS, Adams MA, Turner NC, Ong CK (1998) The redistribution of soil water by tree root 472 systems. Oecologia 115: 306-311.

473 Burgess SS, Adams MA, Turner NC, Beverly CR, Ong CK, Khan AA, Bleby TM (2001) An

474 improved heat pulse method to measure low and reverse rates of sap flow in woody plants. Tree 475 Physiology 21: 589-598.

476 Bush SE, Hultine KR, Sperry JS, Ehleringer JR (2010) Calibration of thermal dissipation sap

477 flow probes for ring-and diffuse-porous trees. Tree Physiology 30: 1545-1554.

478 Cate RB, Nelson LA (1971) A simple statistical procedure for partitioning soil test correlation 479 data into two classes. Soil Science Society of America Proceedings 35: 658-660.

480 Chave J, Rejou-Mechain M, Burquez A, Chidumay E, Colgan MS, Delitti WBC et al. (2014)

481 Improved allometric models to estimate the aboveground biomass of tropical trees. Global

482 Change Biology 20: 3177-3190.

483 Christianson DS, Varadharajan C, Christofferson B, Detto M, Faybishenko BA, Jardine KJ, 484 Negron-Juarez R, Gimenez BO, Pastorello GZ, Powell T, Warren J, Wolfe B, Chambers JC, 485 Kueppers LM, McDowell NG, Agarwal D (2017) A metadata reporting framework for 486 standardization and synthesis of ecohydrological field observations for ecosystem model 487 parameterization and benchmarking. Ecological Informatics 42: 148-58.

488 Christoffersen BO et al. (2016) Linking hydraulic traits to tropical forest function in a size489 structured and trait-driven model (TFS v. 1-Hydro). Geoscientific Model Development 9: 4227.

490 Compo GP et al. (2011) The Twentieth Century Reanalysis Project. Quarterly Journal of the 491 Royal Meteorological Society 137: 1-28. 
492 Cosme LHM, Schietti J, Costa FRC, Oliveira RS (2017) The importance of hydraulic

493 architecture to the distribution patterns of trees in a central Amazonian forest. New Phytologist

494 215: 113-125.

495 Dawson TE, Goldsmith GR (2018) The value of wet leaves. New Phytologist 219: 1156-1169.

496 Detto M, Wright SJ, Calderón O, Muller-Landau HC (2018). Resource acquisition and

497 reproductive strategies of tropical forest in response to the El Niño-Southern Oscillation. Nature 498 communications 9: 913.

499 Dias AS, Oliveira RS, Martins FR, Bongers F, Anten NPR, Sterck F (2019) How do lianas and 500 trees change their vascular strategy in seasonal versus rain forest? Perspectives in Plant Ecology, $501 \quad$ Evolution and Systematics 40: 125465.

502 Edwards WRN, Becker P, Èermák J (1997). A unified nomenclature for sap flow measurements. 503 Tree Physiology 17: 65-67.

504 Eltahir EAB, Bras RL (1994). Precipitation recycling in the Amazon basin. Quarterly Journal of 505 the Royal Meteorological Society 120: 861-880.

506 Fauset S, Baker TR, Lewis SL, Feldpausch TR, Affum-Baffoe K, Foli EG, Hamer KC, Swaine 507 MD, Etienne R (2012) Drought-induced shifts in the floristic and functional composition of 508 tropical forests in Ghana. Ecology Letters 15: 1120-1129.

509 Fisher RA et al. (2015) Taking off the training wheels: the properties of a dynamic vegetation 510 model without climate envelopes, CLM4. 5 (ED). Geoscientific Model Development 3593-3619.

511 Fisher RA et al. (2018) Vegetation demographics in Earth System Models: A review of progress 512 and priorities. Global Change Biology 24: 35-54. 
513 Foley JA et al. (2007) Amazonia revealed: forest degradation and loss of ecosystem goods and

514 services in the Amazon Basin. Frontiers in Ecology and the Environment 5: 25-32.

515 Fonti P, Jansen S (2012) Xylem plasticity in response to climate. New Phytologist 195: 734-736.

516 Fortunel C, Fine PVA, Baraloto C, Dalling J (2012) Leaf, stem and root tissue strategies across

517758 Neotropical tree species. Functional Ecology 26: 1153-1161.

518 Fortunel C, Ruelle J, Beauchene J, Fine PV, Baraloto C (2014) Wood specific gravity and

519 anatomy of branches and roots in 113 Amazonian rainforest tree species across environmental

520 gradients. New Phytologist 202: 79-94.

521 Franks PJ, Cowan IR, Farquhar GD (1997) The apparent feedforward response of stomata to air 522 vapour pressure deficit: information revealed by different experimental procedures with two 523 rainforest trees. Plant, Cell \& Environment 20: 142-145.

524 Good SP, Moore GW, Miralles DG (2017) A mesic maximum in biological water use

525 demarcates biome sensitivity to aridity shifts. Nature Ecology \& Evolution 1: 1883.

526 Gleason SM, Butler DW, Zieminska K, Waryszak P, Westoby M (2012) Stem xylem

527 conductivity is key to plant water balance across Australian angiosperm species. Functional

528 Ecology 26: 343-352.

529 Granier A (1987) Evaluation of transpiration in a Douglas-fir stand by means of sap flow

530 measurements. Tree Physiology 3: 309-320.

531 Griffin-Nolan RJ, Bushey JA, Carroll CJW, Challis A, Chieppa J, Garbowski M, Hoffmann AM, 532 Post AK, Slette IJ, Spitzer D, Zambonini D (2018) Trait selection and community weighting are

533 key to understanding ecosystem responses to changing precipitation regimes. Functional Ecology 534 32: 1746-1756. 
535 Grossiord C, Sevanto S, Borrego I, Chan AM, Collins AD, Dickman LT, Hudson P, McBranch

536 N, Michaletz ST, Pockman WT, Vilagrosa A, McDowell NG (2017) Tree water dynamics in a

537 drying and warming world. Plant, cell \& environment 40: 1861-1873

538 Grossiord C, Sevanto S, Limousin JM, Meir P, Mencuccini M, Pangle RE, Pockman WT,

539 Salmon Y, Zweifel R, McDowell NG (2018) Manipulative experiments demonstrate how long-

540 term soil moisture changes alter controls of plant water use. Environmental and Experimental

541 Botany 152: 19-27

542 Hacke UG, Sperry JS, Pittermann J (2004) Analysis of circular bordered pit function II.

543 Gymnosperm tracheids with torus-margo pit membranes. American Journal of Botany 91: 386-

544400.

545 Hogg EH, Hurdle PA (1997) Sap flow in trembling aspen: implications for stomatal responses to 546 vapor pressure deficit. Tree Physiology 17: 501-509.

547 Kennedy D, Swenson S, Oleson KW, Lawrence DM, Fisher R, Lola da Costa AC, Gentine P 548 (2019) Implementing plant hydraulics in the Community Land Model, version 5. Journal of 549 Advances in Modeling Earth Systems 11: 485-513.

550 Kimball BA, Alonso-Rodríguez AM, Cavaleri MA, Reed SC, González G, Wood TE. (2018)

551 Infrared heater system for warming tropical forest understory plants and soils. Ecology \& 552 Evolution, 8, 1932-1944.

553 Kooperman GJ et al. (2018) Forest response to rising $\mathrm{CO}_{2}$ drives zonally asymmetric rainfall 554 change over tropical land. Nature Climate Change $8: 434$.

555 Koenker R (2017) Quantreg: quantile regression. R package version 5.33. R Foundation for 556 Statistical Computing, Vienna. 
557 Kumagai T, Kanamori H, Chappell NA (2016) Tropical forest hydrology. Forest Hydrology:

558 Processes, Management and Assessment 88-102.

559 Lange OL, Lösch R, Schulze ED, Kappen L (1971) Responses of stomata to changes in

560 humidity. Planta 100: 76-86.

561 Larjavaara M, Muller-Landau HC (2010) Rethinking the value of high wood density. Functional

562 Ecology 24: 701-705.

563 Limousin JM et al. (2012) Morphological and phenological shoot plasticity in a Mediterranean

564 evergreen oak facing long-term increased drought. Oecologia 169: 565-577.

565 Litvak E, McCarthy HR, Pataki DE (2012) Transpiration sensitivity of urban trees in a semi-arid

566 climate is constrained by xylem vulnerability to cavitation. Tree physiology 32: 373-388.

567 Luomala E, Laitinen K, Sutinen S, Kellomäki S, Vapaavuori E (2005) Stomatal density, anatomy

568 and nutrient concentrations of Scots pine needles are affected by elevated $\mathrm{CO} 2$ and temperature.

569 Plant, Cell \& Environment 28: 733-749.

570 Luizão RC, Luizão FJ, Paiva RQ, Monteiro TF, Sousa LS, Kruijt B (2004) Variation of carbon

571 and nitrogen cycling processes along a topographic gradient in a central Amazonian forest.

572 Global Change Biology 10: 592-600.

573 Malhi Y, Wright J (2004) Spatial patterns and recent trends in the climate of tropical rainforest

574 regions. Philosophical Transactions of the Royal Society B: Biological Sciences 359: 311-329.

575 Malhi Y (2009) Exploring the likelihood and mechanism of a climate-change-induced dieback of

576 the Amazon rainforest. Proceedings of the National Academy of Sciences 106: 20610.

577 Mangiafico S (2018) rcompanion: Functions to Support Extension Education Program

578 Evaluation. $\mathrm{R}$ package version 2.0.0. https://CRAN.R-project.org/package=rcompanion 
579 Maréchaux I, Bonal D, Bartlett MK, Burban B, Coste S, Courtois EA, Dulormne M, Goret J-Y,

580 Mira E, Mirabel A, Sack L, Stahl C, Chave J (2018) Dry-season decline in tree sapflux is

581 correlated with leaf turgor loss point in a tropical rainforest. Functional Ecology, doi:

$582 \quad 10.1111 / 1365-2435.13188$.

583 Martinez-Cabrera HI, Jones CS, Espino S, Schenk HJ (2009) Wood anatomy and wood density

584 in shrubs: responses to varying aridity along transcontinental transects. American Journal of 585 Botany 96: 1388-1398.

586 Mayaux P, Holmgren P, Achard F, Eva H, Stibig HJ, Branthomme A (2005) Tropical forest 587 cover change in the 1990s and options for future monitoring. Philosophical Transactions of the 588 Royal Society B: Biological Sciences 360: 373-384.

589 Meinzer FC, Goldstein G, Andrade JL (2001) Regulation of water flux through tropical forest 590 canopy trees: do universal rules apply? Tree Physiology 21: 19-26.

591 Meinzer FC, James SA, Goldstein G, Woodruff D (2003) Whole-tree water transport scales with 592 sapwood capacitance in tropical forest canopy trees. Plant, Cell \& Environment 26: 1147-1155.

593 Meinzer FC, Woodruff DR, Dome, J-C, Goldstein G, Campanello PI, Gatti MG, Villalobos594 Vega R (2008) Coordination of leaf and stem water transport properties in tropical forest trees. 595 Oecologia 156: 31-41.

596 Mencuccini M (2003) The ecological significance of long- distance water transport: short- term 597 regulation, long- term acclimation and the hydraulic costs of stature across plant life forms. 598 Plant, Cell \& Environment 26: 163-182.

599 Moles AT (2018) Being John Harper: Using evolutionary ideas to improve understanding of 600 global patterns in plant traits. Journal of Ecology 106:1-18. 
601 Monteith JL (1995) A reinterpretation of stomatal responses to humidity. Plant, Cell \&

602 Environment 18: 357-364.

603 Moorcroft PR, Hurtt GC, Pacala SW (2001) A method for scaling vegetation dynamics: the 604 ecosystem demography model (ED). Ecological monographs 71: 557-586.

605 Moore GW, Orozco G, Aparecido LM, Miller GR (2018) Upscaling transpiration in diverse 606 forests: Insights from a tropical premontane site. Ecohydrology 11: e1920.

607 Moreira M et al. (1997) Contribution of transpiration to forest ambient vapor based on isotopic 608 measurements. Global Change Biology 3: 439-450.

609 Morris H, Plavcová L, Cvecko P, Fichtler E, Gillingham MA, Martínez-Cabrera HI, McGlinn

610 HI, Wheeler DJ, Zheng E, Ziemińska K, Jansen S (2016) A global analysis of parenchyma tissue 611 fractions in secondary xylem of seed plants. New Phytologist 209: 1553-1565.

612 Murphy PG, Lugo AE (1986) Ecology of tropical dry forest. Annual review of ecology and 613 systematics $17: 67-88$.

614 Myers N, Mittermeier RA, Mittermeier CG, Da Fonseca GA, Kent J (2000) Biodiversity

615 hotspots for conservation priorities. Nature 403: 853.

616 Nejad AR, Van Meeteren U (2007) The role of abscisic acid in disturbed stomatal response

617 characteristics of Tradescantia virginiana during growth at high relative air humidity. Journal of 618 Experimental Botany 58: 627-636.

619 Novick KA et al. (2016). The increasing importance of atmospheric demand for ecosystem water 620 and carbon fluxes. Nature Climate Change 6: 1023.

621 Oishi AC, Hawthorne DA, Oren R (2016) Baseliner: an open-source, interactive tool for 622 processing sap flux data from thermal dissipation probes. SoftwareX 5: 139-143. 
623 Okamoto M, Tanaka Y, Abrams SR, Kamiya Y, Seki M, Nambara E (2009) High humidity

624 induces abscisic acid 8 '- hydroxylase in stomata and vasculature to regulate local and systemic

625 abscisic acid responses in arabidopsis. Plant Physiology 149L: 825-834.

626 Oren R, Sperry JS, Katul GG, Pataki DE, Ewers BE, Phillips N, Schäfer KVR (1999) Survey and

627 synthesis of intra-and interspecific variation in stomatal sensitivity to vapour pressure deficit.

628 Plant, Cell \& Environment 22 : 1515-1526.

629 Poyatos R, Martínez-Vilalta J, Čermák J, Ceulemans R. Granier A, Irvine J, Köstner B,

630 Lagergren F, Meiresonne L, Nadezhdina N, Zimmermann R, Llorens P, Mencuccini M (2007)

631 Plasticity in hydraulic architecture of Scots pine across Eurasia. Oecologia $153: 245-259$.

632 Poyatos R, Granda V, Molowny-Horas R, Mencuccini M, Steppe K, Martínez-Vilalta J (2016)

633 SAPFLUXNET: towards a global database of sap flow measurements. Tree Physiology 36:

$634 \quad 1449-1455$.

635 R Core Team (2015) R: A language and environment for statistical computing. R Foundation for

636 Statistical Computing, Vienna, Austria. URL http://www.R-project.org/.

637 Reich PB, Walters MB, Ellsworth DS (1997) From tropics to tundra: global convergence in plant

638 functioning. Proc Natl Acad Sci USA 94: 13730-13734

639 Reich PB (2014) The world-wide 'fast-slow'plant economics spectrum: a traits manifesto.

640 Journal of Ecology 102: 275-301.

641 Richards PW (1952) The tropical rain forest; an ecological study. At The University Press;

642 Cambridge.

643 Schachtman DP, Goodger JQ (2008) Chemical root to shoot signaling under drought. Trends in 644 plant science 13: 281-287. 
645 Schlesinger WH, Jasechko S (2014) Transpiration in the global water cycle. Agricultural and 646 Forest Meteorology 189: 115-117.

647 Schulze E-D, Lange OL, Buschbom U, Kappen L, Evenari M (1972) Stomatal responses to 648 changes in humidity in plants growing in the desert. Planta 108: 259-270.

649 Slot M, Winter K (2017) In situ temperature response of photosynthesis of 42 tree and liana 650 species in the canopy of two Panamanian lowland tropical forests with contrasting rainfall 651 regimes. New Phytologist 214: 1103-1117.

652 Stahl C, Burban B, Wagner F, Goret JY, Bompy F, Bonal D (2013a) Influence of Seasonal

653 Variations in Soil Water Availability on Gas Exchange of Tropical Canopy Trees. Biotropica 45:

654 155-164.

655 Stahl C, Hérault B, Rossi V, Burban B, Bréchet C, Bonal D (2013b) Depth of soil water uptake 656 by tropical rainforest trees during dry periods: does tree dimension matter? Oecologia 173: 11916571201.

658 Steppe K, De Pauw DJ, Doody TM, Teskey RO (2010) A comparison of sap flux density using 659 thermal dissipation, heat pulse velocity and heat field deformation methods. Agricultural and 660 Forest Meteorology 150: 1046-1056.

661 Swenson NG et al. (2017) Tree co-occurrence and transcriptomic response to drought. Nature 662 communications 8: 1996.

663 Togashi HF et al. (2015) Morphological and moisture availability controls of the leaf area- to664 sapwood area ratio: analysis of measurements on Australian trees. Ecology \& Evolution 5: 12636651270. 
666 Torre S, Fjeld T (2001) Water loss and postharvest characteristics of cut roses grown at high or 667 moderate relative air humidity. Scientia Horticulturae 89: 217-226.

668 Torre S, Fjeld T, Gislerød HR, Moe R (2003) Leaf anatomy and stomatal morphology of 669 greenhouse roses grown at moderate or high air humidity. Journal of the American Society for 670 Horticultural Science 128: 598-602.

671 van der Sande MT et al. (2016) Old-growth Neotropical forests are shifting in species and trait 672 composition. Ecological Monographs 86: 228-243.

673 Whitehead D, Okali DUU, Fasehun FE (1981) Stomatalresponse to environmental variables in 674 two tropical forestspecies during the dry season in Nigeria. Journal of Applied Ecology 18: 571675587.

676 Wolf A, Anderegg WR, Pacala SW (2016) Optimal stomatal behavior with competition for water 677 and risk of hydraulic impairment. Proceedings of the National Academy of Sciences 113: E7222678 E7230.

679 Wood PJ, Hannah DM, Sadler JP (Eds.) (2008) Hydroecology and ecohydrology: past, present 680 and future. John Wiley \& Sons.

681 Wright IJ et al. (2004) The worldwide leaf economics spectrum. Nature 428: 821-827.

682 Wright IJ et al. (2005) Modulation of leaf economic traits and trait relationships byclimate. Glob.

683 Ecol. Biogeogr. 14: 411-421.

684 Wright IJ et al. (2007) Relationships Among Ecologically Important Dimensions of Plant Trait 685 Variation in Seven Neotropical Forests. Annals of Botany 99: 1003-1015. 
686 Xu X, Medvigy D, Powers JS, Becknell JM, Guan K (2016) Diversity in plant hydraulic traits

687 explains seasonal and inter-annual variations of vegetation dynamics in seasonally dry tropical

688 forests. New Phytologist 212: 80-95.

689 Zemp DC, Schleussner CF, Barbosa HMJ, Van der Ent RJ, Donges JF, Heinke J, Sampaio G,

690 Rammig A (2014) On the importance of cascading moisture recycling in South America.

691 Atmospheric Chemistry and Physics 14: 13337-13359.

692 Zhang K, Kimball JS, Nemani RR, Running SW, Hong Y, Gourley JJ, Yu Z (2015) Vegetation

693 greening and climate change promote multidecadal rises of global land evapotranspiration. Sci.

694 Rep. 5: doi:10.1038/srep15956.

695 Zhu SD, Song JJ, Li RH, Ye Q (2013) Plant hydraulics and photosynthesis of 34 woody species

696 from different successional stages of subtropical forests. Plant Cell Environ 36: 879-891.

697 Ziemińska K, Westoby M, Wright IJ (2015) Broad Anatomical Variation within a Narrow Wood

698 Density Range-A Study of Twig Wood across 69 Australian Angiosperms. PLoS ONE 10:

$699 \mathrm{e} 0124892$. 
700 Table 1: Characteristics of the study sites

\begin{tabular}{|c|c|c|c|c|c|c|c|}
\hline Site code & PNM & MAN & BCI & FRG & SLZ & SAB & SOL \\
\hline Country & Panama & Brazil & Panama & French Guiana & Panama & Puerto Rico & Costa Rica \\
\hline$M A T^{*}\left({ }^{\circ} \mathrm{C}\right), M A P^{*}(\mathrm{~mm})$ & 26,1826 & 27,2200 & 26,2640 & 26,3102 & 25,3286 & 24,3500 & 24,4200 \\
\hline$P_{D R Y^{*}}(\mathrm{~mm})$ & 53 & 95 & 60 & 72 & 70 & 90 & 100 \\
\hline Topography & Light slope & Flat & Flat & Light slope & Steep & Light slope & Steep \\
\hline Soil depth $(m)$ & $>6$ & $>20$ & NA & $>15$ & $>3$ & $>20$ & 1.5 \\
\hline Elevation $(m)$ & 30 & 100 & 170 & 40 & 130 & 130 & 540 \\
\hline Mean LAI* $\left(m^{2} m^{-2}\right)$ & NA & 6.0 & 6 & 6.7 & NA & 6.47 & 3.32 \\
\hline Soil type & Mollisol & Latosol & Oxisol & Acrisols & Oxisol & Ultisol & Andisol \\
\hline MET station $(m)^{*}$ & 25 & 50 & 48 & 56 & 52 & 2 & 42 \\
\hline Sap flux method & $\mathrm{TD}$ & HR & $\mathrm{TD}$ & $\mathrm{TD}$ & HR & $\mathrm{TD}^{*}$ & $\mathrm{TD}$ \\
\hline $\begin{array}{l}\text { Duration of the } \\
\text { measurements (months) }\end{array}$ & 12 & $2-5$ & 16 & 24 & 13 & 12 & 21 \\
\hline References & $\begin{array}{c}\text { Slot \& Winter, } \\
2017\end{array}$ & $\begin{array}{l}\text { Luizão et } \\
\text { al., } 2004\end{array}$ & $\begin{array}{l}\text { Detto } \text { et } \\
\text { al., } 2018\end{array}$ & $\begin{array}{l}\text { Bonal et al., } \\
\quad 2008\end{array}$ & $\begin{array}{c}\text { Slot \& } \\
\text { Winter, } 2017\end{array}$ & $\begin{array}{l}\text { Kimball et } \\
\text { al., } 2018\end{array}$ & $\begin{array}{l}\text { Aparecido } \\
\text { et al., } 2016\end{array}$ \\
\hline
\end{tabular}

701 *MAP, mean annual sum of precipitation (1950-2010); MAT, mean annual temperature (1950-2010); $P_{D R Y}$, mean monthly sum of precipitation

702 during the dry season; LAI, leaf area index; HR, heat-ratio method; TD, thermal dissipation method; MET station, height of the meteorological

703 station (m) 
704 Table 2: Characteristics of the study trees ( \pm SE).

\begin{tabular}{|c|c|c|c|c|c|}
\hline Site & $\begin{array}{c}\text { Number of } \\
\text { measured trees }\end{array}$ & $\begin{array}{l}\text { Mean tree } \\
\text { height }(m)\end{array}$ & $\begin{array}{c}\text { Mean } D B H^{*} \\
(\mathrm{~cm})\end{array}$ & $\begin{array}{r}\text { Number } \\
\text { target spe }\end{array}$ & cies \\
\hline PNM & 4 & $30.7 \pm 2.7$ & $83.9 \pm 18.9$ & 4 & 708 \\
\hline MAN & 4 & $32.2 \pm 1.5$ & $59.9 \pm 9.6$ & 4 & 709 \\
\hline BCI & 6 & $26.6 \pm 2.0$ & $47.3 \pm 6.7$ & 5 & 710 \\
\hline FRG & 5 & $27.8 \pm 2.1$ & $40.3 \pm 10.9$ & 5 & 711 \\
\hline SLZ & 6 & $28.1 \pm 1.5$ & $49.9 \pm 4.5$ & 6 & 712 \\
\hline SAB & 9 & $23.4 \pm 0.9$ & $28.8 \pm 1.8$ & 8 & 713 \\
\hline SOL & 8 & $30.1 \pm 1.1$ & $96.7 \pm 24.5$ & 4 & 714 \\
\hline
\end{tabular}

$715 * D B H=$ diameter at breast height 


\section{Figure legends}

717 Figure 1: Theoretical variation in sap flux velocity $(v)$ response to $V P D$ : under low $V P D$

718 conditions, $v$ increases linearly with rising $V P D$ until $v$ reaches a saturation rate ( $v_{\max }$, grey circle)

719 at a given $V P D$ threshold ( $V P D_{\max }$, grey arrow). As $V P D$ progressively increases $v$ will either

720 level-off at a maximum rate or start dropping progressively. Differences in $v$ responses to

721 increasing VPD between trees (highlighted by different dotted and bold lines) emerge from long-

722 term adjustments to local moisture conditions (i.e. reflecting differences in foliar and wood

723 hydraulic properties), with reductions in moisture expected to result in lower $V P D_{\max }$ and $v_{\max }$.

724 Figure 2: Sub-hourly sap flux velocity $\left(v, \mathrm{~cm} \mathrm{~h}^{-1}\right)$ as a function of vapor pressure deficit $(V P D$,

$725 \mathrm{kPa}$ ) for each site. Sites are organized going from the driest (b) to the wettest (h) (i.e. in terms of

726 MAP). Dashed lines represent fitted curves using local regression function for each individual

727 tree.

728 Figure 3: Relationships between the $V P D$ threshold at which sap flux levels-off at maximum

729 levels $\left(V P D_{\max } \pm \mathrm{SD}, \mathrm{kPa}\right)$ and maximum sap flux $\left(v_{\max } \pm \mathrm{SD}, \mathrm{cm} \mathrm{h}^{-1}\right)$, and mean annual

730 precipitation $(M A P, \mathrm{~mm})$ (panels a and c) or monthly precipitation during the dry season $\left(P_{D R Y}\right.$,

$731 \mathrm{~mm}$ ) (panels $\mathrm{b}$ and $\mathrm{d}$ ). Asterisks, situated next to the $r^{2}$ values, denote the significance of the

732 relationships $(* P<0.05, * * P<0.01, * * * P<0.001)$

733 Figure 4: Relationships between $V P D$ threshold at which sap flux levels-off at maximum levels

$734\left(V P D_{\max }, \mathrm{kPa}\right)$ and maximum sap flux $\left(v_{\max }, \mathrm{cm} \mathrm{h}^{-1}\right)$, and wood specific gravity $\left(W S G, \mathrm{~g} \mathrm{~cm}^{-3}\right)$

735 (panels a and $\mathrm{c}$ ) or leaf mass per area $\left(L M A, \mathrm{~g} \mathrm{~m}^{-2}\right)$ (panels $\mathrm{b}$ and $\mathrm{c}$ ), across all sites. Each point

736 represents a different individual tree. 


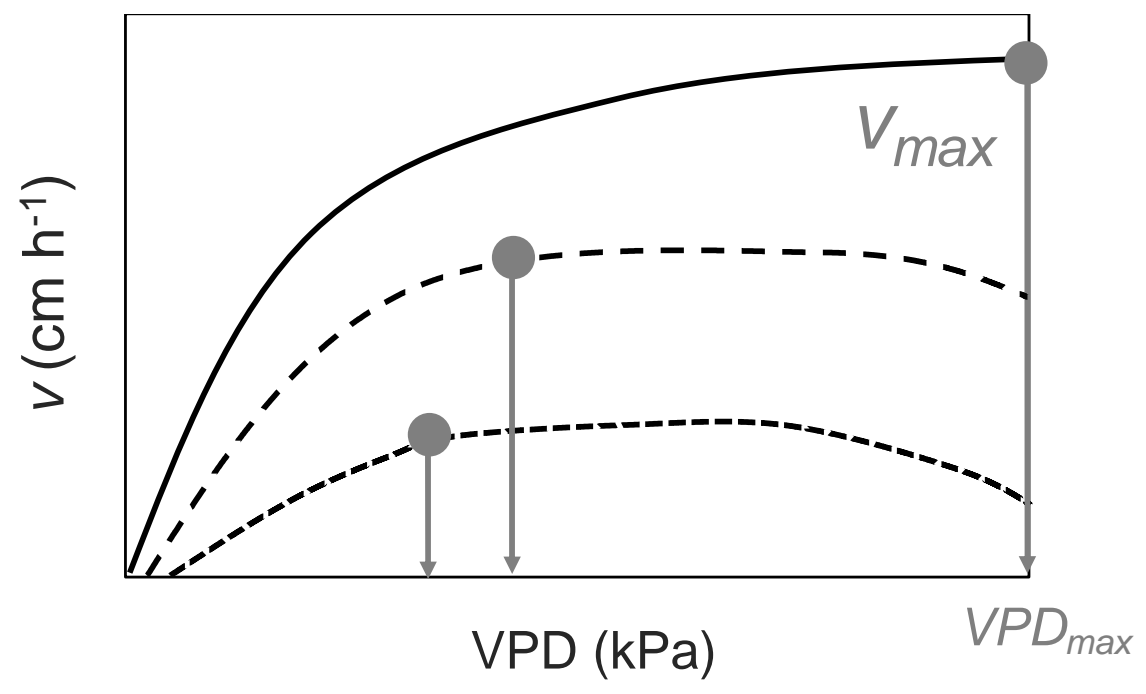

Figure 1 


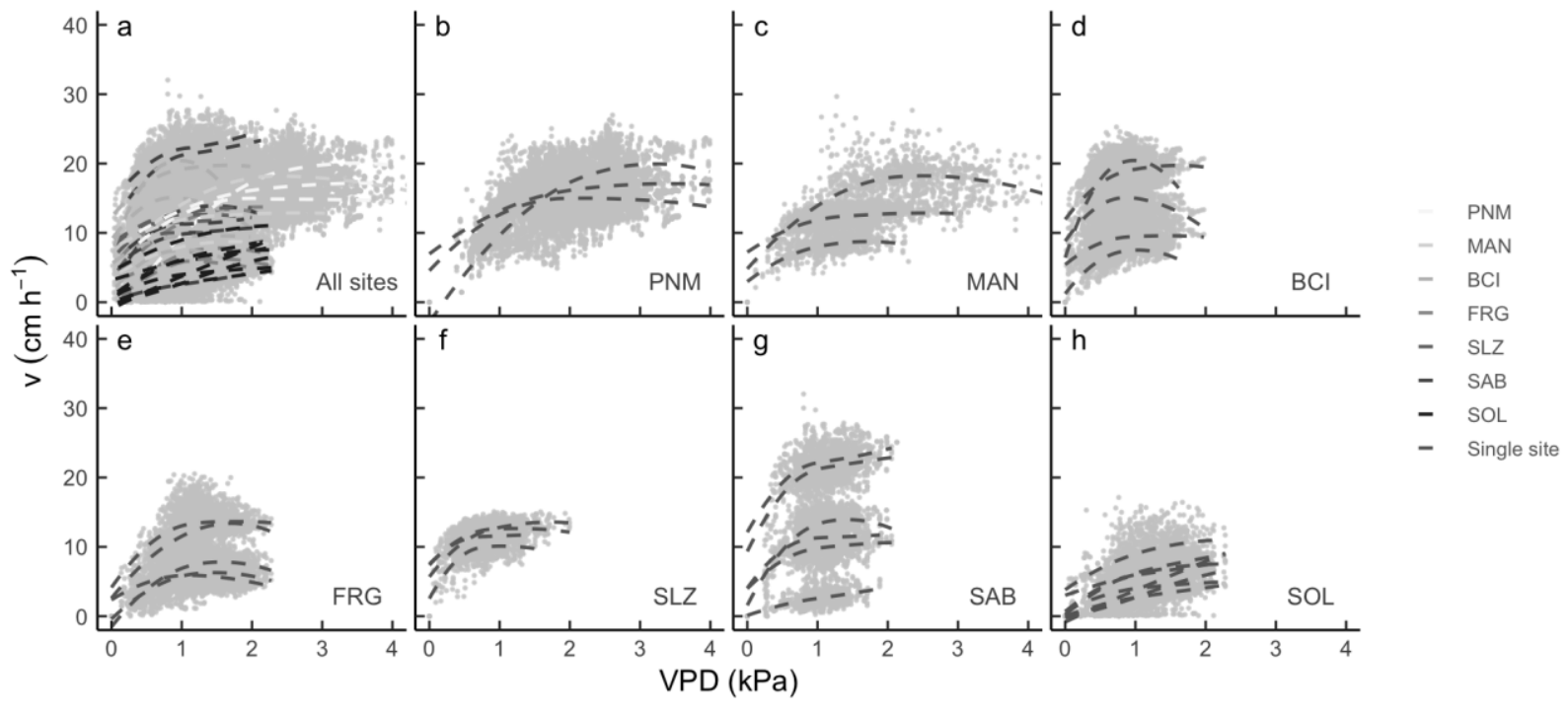

Figure 2 


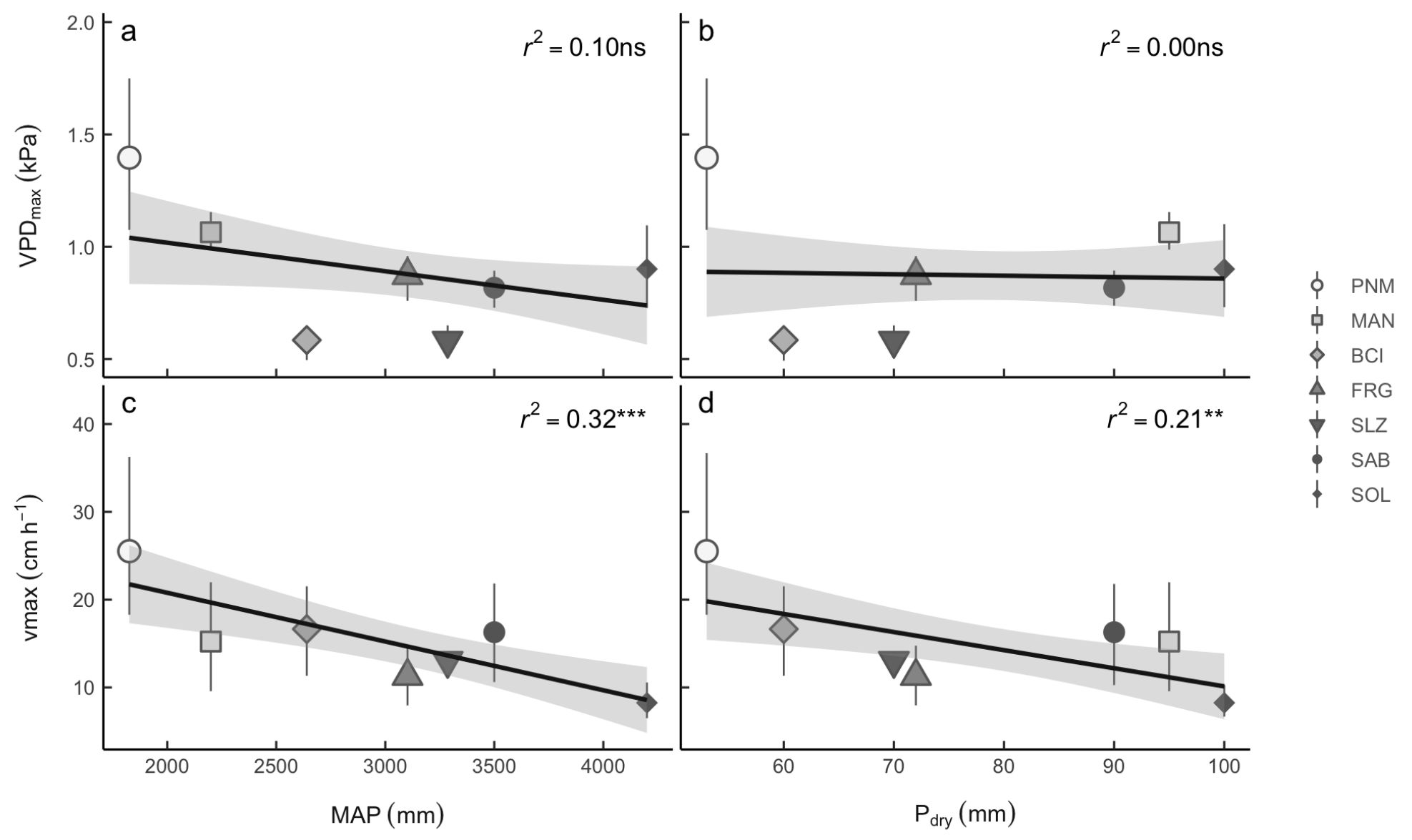

Figure 3 


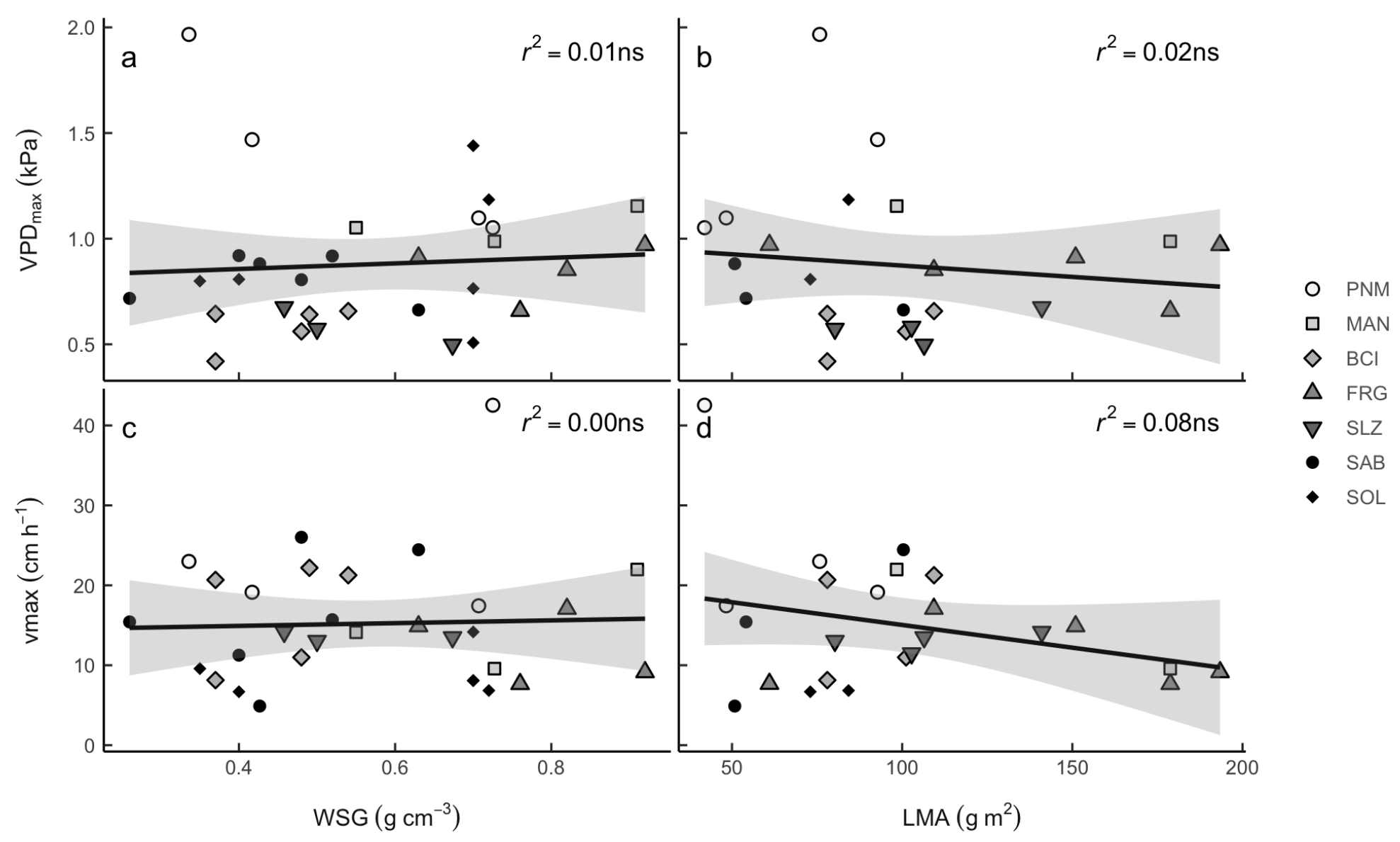

747
748

Figure 4 